\title{
Lora, a Beatricean Image in the Albanian Poetry
}

\author{
Aristidh Çipa \\ University "Ismail Qemali", Vlorë - Albania \\ Faculty of Human Sciences \\ Department of Albanian Language and Literature \\ E-mail: aristidhcipa@hotmail.com
}

\section{Doi:10.5901/jesr.2013.v3n7p472}

\begin{abstract}
Frederik Rreshpja1 - an exceptionally impressive poet - is considered as one of the Albanian contemporary poetry modelers. As part of the avant-garde poets of the seventies, after suffering a seventeen years political imprisonment, in 1991 he comes renewed and strong in the elite spectrum of the Albanian poetry and becomes a reference point for the new poetry. The author plays a substantial role in shaping the esthetic and fragile conscience of the new generation. This modest work is aimed at providing the authentic experience of Rreshpja in constructing a lyrical image of the adored female model. It must be noted that, coming from Dukagjin - an entirely epic and mountainous region of Albania - the poet is also in an epic mood. A great part of his lyrical poetry lexicon is also epic. In his region of origin, women have always been painted in sacred colors that even Reshpja has inherited: he portrays an idealized woman bearing amplified qualities. The poet's behavior is that of a real knight with strong medieval reminiscences and ancient redolence. In the poet's opinion, women are a very delicate issue to be dealt with...
\end{abstract}

Rreshpja never really married. So far, there are no convincing grounds to make us believe that the poet Frederik Rreshpja might have had an exceptional crush on a real woman. To him, women were a very delicate issue to be dealt with, and generally he would avoid conversations about them. The presence of a woman would make him abandon his fellows and engage himself in a sweet conversation with her. He paid special attention to this woman while his face radiated a gentle smile, his voice became soft and tender, and the body shrank as to avoid direct eye contact with her. However, as the conversation went on, a sense of excitement and pleasure would raise inside him so strong as to be reflected in his eyes, skin and gestures. He would abandon the irritation, the anger, the sorrow and the solitude and slowly transform into another man, whose appearance suddenly emitted gentleness, care, good manners and tenderness. And yes, he became a happy man! Yet, it was but a particular woman to alter his state of mind. He adored all women. The unique entity of the female gender crossed his vivid imagination and immediately carried a divine charm and light. The appearance did not matter; pretty or not, every woman could enter the fantasy of Rreshpja and suddenly be a naiad, a nymph, an Illyrian goddess, the legend of Rozafa, an autumn day, a rose, a lily, any beautiful flower.

As his friends confirm, Rreshpja was very shy with women and almost always their presence provoked new situations and produced a kind of reaction in Rreshpja's appearance, attitude and communication style. This may be due to the rare contacts he has had with women throughout his lifetime. Indeed, he married only once but unfortunately the spouse left him in three days causing a great solitude in the poet's life. So short was the duration of his marriage as to question its actual consummation. Moikom Zeqo, a good friend and connoisseur of Rreshpja's personality and psychological profile, goes further and writes, "This man created a cult of his mother. I don't know why, but I think no other woman has ever entered his life except for an invented Beatricean character called Lora - so much sorrow, so little love in the life of this man!" (In memoriam of Frederik Rreshpja, "Koha Jone",18.02.2006).

The cult of his mother is present in many poetries of Rreshpja, whereas some of these poetries are dedicated exceptionally to her. To be mentioned are: "To my mother", "Mother", "Mother's hometown", "Elegy for a mother", "Ave, my mother". In addition, he dedicated to his mother a poetic collection entitled "Solitude": "To my mother, who has suffered my prison, deportation and hospital pains. With compassion, Frederik Rreshpja".

The main reason why we may possibly accept the supposition of the poet and scholar M. Zeqo - "I think no other

11940 - 2006 Author of some poetry volumes like "Albanian Rhapsody", "In this city", "It's time I die again", "The Solitude", etc. His works have been translated in English, Russian, German, Italian, etc., and have been evaluated by researchers and critics as thrilling poetry works of European standard. It is represented in the Italian magazine "Lo Straniero", no.94, in April 2008. 
woman has ever entered his life" - is that Zeqo has been a close friend of Rreshpja, to whom the poet himself might have had revealed some secrets on the subject. Furthermore, it is the poetic creativity of Rreshpja and the sublimation of the female image in his lyrical poetry to reinforce the supposition of $\mathrm{M}$. Zeqo. People always tend to exalt and praise what they miss or cannot have. The vivid poetic imagination of Rreshpja embraced an acclaimed and idolized unique woman, who should have a conceivable name to be accepted by the readers and the poet himself. The poet has always shown a knightly attitude toward women: he was gentle, good, kind and ready to serve them. On the other hand, coming from Dukagjin - an entirely epic and mountainous region of Albania - the poet is also in an epic mood. A great part of his lyrical poetry lexicon is also epic: rhapsodist, ballad, lute, lliad, mountains, Ajkuna, Rozafa, or the following verses:

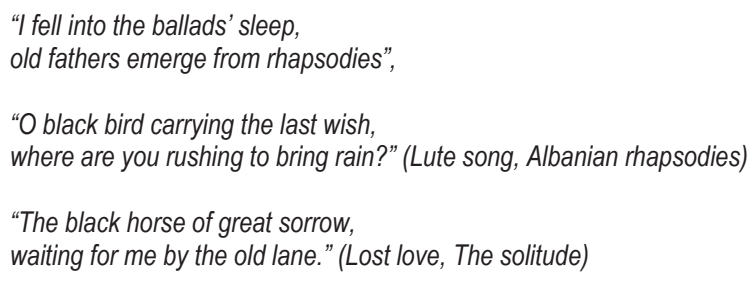

In such an epic atmosphere, the female image has historically had sacral colors, which naturally have been inherited even by Rreshpja. As far as the linguistic articulation is concerned, there is a three-dimensional female image in Rreshpja's poetries: as a mother, as a sister, and as a wife. With respect to the lover female image, it existed not as an articulable concept, but as a hidden reality, a myth, a dream, something to aim at, an imaginary entity, which gave a man's life a new shape and meaning. Consequently, his idealized woman had such hyperbolized qualities as to catch the attention and passion of a man. From this point of view, the female image is the reason for many men's courageous deeds - a knightly attitude with heavy medieval reminiscences and a strong smell of ancientness. In a way or another, the adorable woman painted by Rreshpja was an orientation point to motivate and justify any man's actions and deeds. She could have an easily pronounceable name or no name at all, thus existing as a possibility, as a fantasy.

Nevertheless, Rreshpja had no real female image. He created a perfect female out of his flamboyant imagination, by capturing any distinct feature of every female he had encountered in his life and called her Lora. The image of this acclaimed female has been incessantly depicted in Rreshpja's poetries, although bearing no specific and definite name. The same female archetype is exalted in his lyrical kingdom. Let us consider the following verses:

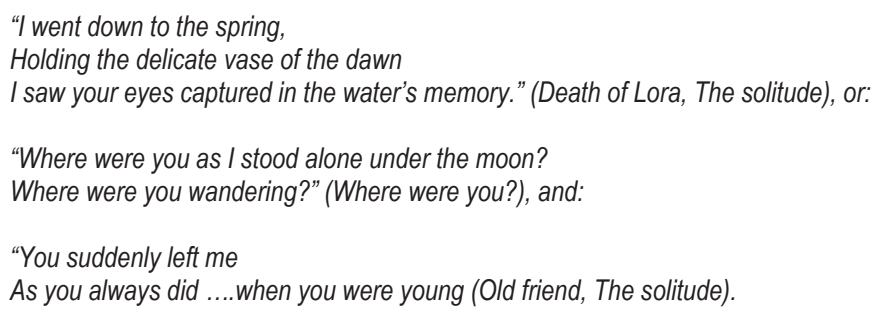

However, sometimes the image of this unique female emerges from the past bearing no physical desire function: "We have been kissing through old lliads/ as Homers played the harp." Frequently, the image of this mysterious female is sheltered inside the context of lost love, far away from the poet:

"Ah! In this immense world, you and I only,

will no longer be happy..."(Sunset, The solitude).

Sometimes, the poet tries to convince us that this woman is no longer living:

"Now that the time is gone,

I know my love won't bring you back" (I keep on staying, In solitude)

And sometimes, she is present:

"Please stay with me tonight,

and wait till roses flourish from the dead woods" (Stay tonight!, In solitude) 
As one may notice, this female image extends over all times and it is present in most of Rreshpja's poems. Illusive as it may be, the poet makes it poetically believable. The name of this mirage-woman finally is made known at the end of Rreshpja's life and creativity. It appears only once in the title of a poem taken from the collection "In solitude", published in 2004 by the publishing house "Arberia:

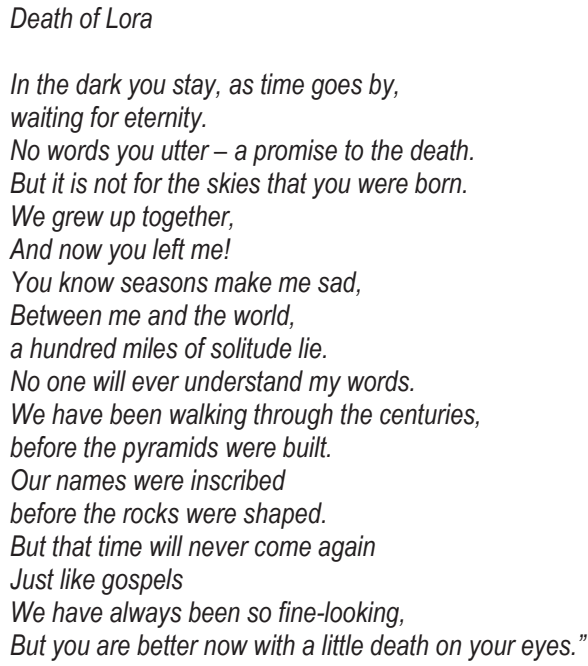

However, the poem "Death of Lora" ends differently in the collection "Solitude" published by the publishing house "Medaur" just a few months before the above collection, "In solitude". In the first version, the poem continues with other fifteen verses, which, for some strange reasons - they are in harmony with the initial part of the poem and of the same esthetic and emotional level - have been removed in the later version.

\author{
"My love won't bring you back \\ The night is full of your absence, \\ Every night, \\ And such will it be, till the end of all nights. \\ I went down to the spring, \\ Holding the delicate vase of the dawn \\ I saw your eyes captured in the water's memory. \\ The old oak relinquished the autumn's crown \\ Like and abdicating sovereign \\ And I am cursed. \\ Oh! My darling, come and speak to the seasons. \\ These woods will never be the same without you. \\ The autumn will never go, \\ Or maybe it will never come. \\ In the name of who are leafs to fall down? \\ In the name of who are rains, fogs and bows to come?"
}

Just as M. Zeqo (mentioned above), the poet Azem Qazimi highlights the existence of an ideal imagination and of a personal mythology of Rreshpja, "A mind shaped by myths, always trying to conceive its ideal entity, its Dulcinea (or Beatrice), inside a net of scenarios and inducements, under a favorable light to its ambition." (Fredi, a boundless shape of the scandal), "Koha Jone", 24.12.2005).

In various texts, birth anniversaries and homage dedicated to Rreshpja, many poets and scholars compare Lora to Laura of Petrarch (maybe due to the name resemblance) and to Beatrice. However, the poet Azem Qazimi considers 
Lora more similar to Dulcinea of Cervantes. Referring to Dulcinea, Harold Bloom says: "Miguel de Unamuno, as well as I, took very seriously the sublime considerations of Don over Aldonza Lorenzo and her later laudation ala Beatrice as the angelic, though unfortunately enchanted Dulcinea; this helps us contemplate the knight's whole complexion. He lives in hope, although he is aware of his own fiction, as his lucidity outbreaks may confirm. Dulcinea is a supreme fiction, whereas Don Quixote is a bewitched reader, a poet of action who created an outstanding myth. (Harold Bloom, Western Canon, 5. Cervantes: The World's Game, page 129)

Apparently, Bloom, while quoting Dulcinea, takes the opportunity to mention Beatrice as the archetype of fictional characters. However, according to the famous critic, the frequent lucidity outbreaks of Don Quixote reveal his awareness of the fiction. To be noted is the fact that Dulcinea is an imaginary character inside a fictional one that is Don Quixote, and Cervantes accepts both characters as creatures of his imagination. When it comes to Lora, Rreshpja was the first to believe in this fictional character. No one would ever dare to say that Lora existed solely in the poet's mind. The knightly profile of Rreshpja's personality is a good reason to consider the suggestion of A. Qazimi. Generally, the comparison to Beatrice, who is a character of poetry and not of prose, seems more charming than reliable.

Referring to the image of Beatrice in the "Devine Comedy" of Dante, Bloom quotes, "Since Beatrice, initially was just a necessary means of Dante's desire, her deification includes even the choice of Dante... Dante would never accept the Comedy as a fiction, his fiction is supreme. To him, the poem is the truth itself, the universal, not temporary truth...What Williams emphasizes in his deep study, the Figure of Beatrice (1943) is the main (wonderful) scandal of Dante's achievements: the greatest fiction of the poet is Beatrice. Not even the Shakespearean characters, the charismatic Hamlet and the divine King Lear could compare to Beatrice as an extremely brave fictional character...Placing Beatrice inside the Christian machinery of redemption is the bravest action to transform the inherited religion in something much more personal. (pg. 72-73)...Beatrice occupies a certain position in the divine hierarchy, which is difficult to understand. We apply no estimating standards; there is nothing in the doctrine to explain the exaltation of this special Florentine woman, with whom Dante was passionately in love...." ("Western Canon, 3. The Strangeness of Dante: Ulysses and Beatrice", pg. 74-75).

The existence of Lora is an exceptional phenomenon in the Albanian literature as far as a poet's imagination and ability to give his soul to a fictional character are concerned. Rreshpja not only believes in the existence of Lora, but, having known her since his childhood, he has fallen desperately in love with her. Consider what Rreshpja himself says about Lora: "Lora is the tear of my poetry. I loved her because she loved me so much. She is the one to have loved me so much in this world, except for my mother...Destiny wanted that we were classmates. I have always learned better than the other schoolmates. She wanted me... One day the teacher sent her to my desk. I said, "Why did you come here"? "The teacher told me you are the most quiet" (she said). This happened in the seventh grade. As we walked down the road, she kept teasing me... "Can I come to your house tonight?" she said. "What for...god forbid...my father will kill us", said I. "But, I love you", she replied. "What are you talking about? You shouldn't talk like that. You are a good girl, not a whore...And I am a good boy too, well-conducted and catholic". But she never gave up. She managed to come to my house, until her father got her and ordered the doctors to kill her... "I don't want a daughter that goes with an enemy...", he had said. They separated us, although I had done nothing...I was not an enemy...I had done nothing" (My life, a worthless journey", interview with Frederik Rreshpja, "Gazeta Shqiptare", 19 March 2005).

When the name of Lora comes out, Rreshpja cannot hold his tears - a clear evidence that the poet not only believes in the existence of Lora, but that he suffers so much as to reflect it in his sensitive and touching lyric poetries. Sometimes explicitly and sometimes implicitly, just as planets go around a star, the entire lyrical body of Rreshpja goes around this image. One year before his death, the poet baptized this image with the name of Lora. The name of this mysterious woman has greatly influenced upon the quality of Rreshpja's poetry as it has been transformed in the center of his spiritual pilgrimage. She has been an extraordinary incentive to the Rreshpja's poetry bearing incomparable figurative colors to inspire and enrich the entire Albanian poetry.

\section{References}

Rreshpja, F. (1968). Albanian Rhapsody - Poetry collection. Tirana: Publishing House 8 Nentori.

Rreshpja, F. (1973). In this city - Poetry collection. Tirana: Publishing House 8 Nentori.

Rreshpja, F. (1994). It's time I die again - Poetry collection. Tirana: Publishing House 8 Nentori.

Rreshpja, F. (2004). Solitude - Poetry collection. Tirana: Publishing House Medaur

Rreshpja, F. (2004). In Solitude - Poetry collection. Tirana: Publishing House Arberia

Bloom, H. (1994). The Western Canon, 3 - The strangeness of Dante: Ulysses and Beatrice. New York: Riverhead Books pp. 74-75.

Bloom, H. (1994). The Western Canon, 5 - Cervantes: The World's Game. New York: Riverhead Books pp. 129. 
Ungaretti, G. Montale, E. Quasimodo, S. (1972). Collection of works. Mondadori. Jimenez, J.R. (2005). Poetries. Tirana: Ombra GVG. Lorca, F.G. (2005). Poetries. Tirana: Ombra GVG.

Zeqo, M. (2003, December 15). Frederik Rreshpja - The great loner. Republika. Lanksch, H.J. (2004, December 25). Don't feel sorry for my fate. Republika. Bejko, S. (2006, February 19). The last bohemian of the Albanian poets. Shekulli. Kelmendi, Sh. (2006, February 19). The poetry ship mourns the old captain. Koha Jone. Zeqo, M. (2006, February 18). In Memorian of Frederik Rreshpja, Koha Jone.

(2005, December 24). Fredi, a boundless shape of the scandal. Koha Jone. (2005, March 19). My life is a vain journey. Interview with Frederik Rreshpja. Gazeta Shqiptare. (2005, July 31). Paramount Poetry, Journal "Temp". 